\title{
Effect of Planting Methods and Intercropping Green and Full Mature Onion with Wheat
}

\author{
Zen EI-Dein, A.A.M. ${ }^{1}$ and A.I. Yahya ${ }^{2}$ \\ ${ }^{1}$ Crop Intensification Research Sec., ${ }^{2}$ Wheat Research Department, Field Crops Research \\ Institute, ARC
}

\begin{abstract}
Two field experiments were conducted at Etay El-Baroud Experiment station of ElBehira Governorate, Egypt during 2017/2018 and 2018/2019 seasons to examine three planting methods of intercropping green and full mature onion with wheat i.e. 1-planting in flat soil (without ridges), wheat was planted in rows $20 \mathrm{~cm}$ apart and onion was transplanted among the rows of wheat, 2-growing wheat on ridges $(60 \mathrm{~cm}$ apart) in 2 rows on top and northern side of the ridge and onion was transplanted on southern side of the same ridge and 3-growing wheat on the wide ridges (120cm apart) in 4rows and onion was transplanted on both sides of the same ridge and two intercropping systems $(100 \%$ wheat + $50 \%$ green onion and $100 \%$ wheat $+50 \%$ full mature onion as well as sole wheat, sole green and full mature onion. Results show that, planting methods had no significant effect on yield and its components of wheat, except spike length and number of spikes $/ \mathrm{m}^{2}$ were significantly affected by planting methods in the two growing seasons while, 1000 grain weight was significantly affected by planting methods in $2018 / 2019$ season only. The tallest spikes length were recorded under planting method $\left\{120 \mathrm{~cm}\left(\mathrm{M}_{3}\right)\right\}$ while, the highest number of spikes $/ \mathrm{m}^{2}$ and 1000 grain weight were recorded under planting method \{without ridges $\left(\mathrm{M}_{1}\right)$ \}. On the other hand, green and full mature onion per feddan were significantly affected by planting methods, the highest main values were recorded by growing onion on the two sides of ridges $\{120 \mathrm{~cm}$ apart (M3)\}. Intercropping green and full mature onion had no significant effect on yield of wheat, while the sole onion achieved the highest yield/fed compared to intercropping systems. Generally, growing green onion on the two sides of wide ridges $\{120 \mathrm{~cm}$ apart (M3) $\}$ with wheat recorded the highest Land Equivalent Ratio (LER), Relative Crowding Coefficient (K) and net returns compared to sole wheat. In all intercropping treatments, wheat was the dominant whereas, onion was the dominated.
\end{abstract}

Keywords: Wheat, Onion, Intercropping systems, Equivalent yield and Net return.

\section{INTRODUCTION}

Wheat is one of the most important food grain crops grown in Egypt and in the world. It ranks first in the world cereal crops accounting for $30 \%$ of all cereal food worldwide and is a staple food for over 10 billion people in as many as 43 countries of the world. It provides about $20 \%$ of the total food calories for the human race.

Intercropping system is a well known technique in vegetable production in some particular areas of Egypt because of the small from land ownership. Growers with such small areas are always looking for maximizing their farm income through vertical expansion. Vertical expansion can be achieved by either cultivating the land more than once per year and/or intercropping. Intercropping through more effective use of water, nutrients and solar energy, can significantly enhance land crop productivity compared to the growth of sole crops (Baumann et al., 2001). It has also a positive effect on soil conservation and improvement of soil fertility (Black,1965), more effective use of natural resources (Midmore ,1993) and great production. Intercropping can afford the diminution of the risks of total loss, the better control over erosion, the control of weeds and the potential of greater sources of profits (Brown et al., 1985).The advantages of intercropping in better land use efficiency as an important component of sustainable 
farming has been demonstrated by Guvence and Yildirim (1999).Cultivars suitable for intercropping should enhance the complementary effects between species. These studies have indicated that intercropping was more productive than sole cropping due to the complementary effects of intercrops. In successful intercropping systems, timing of production is an important factor in order to avoid competition among growing crops and conflicts in agricultural practices in particular harvesting.

The objective of this study was to maximize land use efficiency cultivated with wheat by using some intercropping systems of green onion (vegetables) and full mature onion deferent in their time of harvest.

\section{MATERIAL AND METHODS}

The present study was conducted at Etay El-Baroud Experiment station at ElBehera Governorate, Egypt during 2017/2018 and 2018/2019 seasons to investigate the effect of intercropping \{ green and full mature onion $\}$ on wheat, within three growing systems of wheat and onion as well as its effect on usage of land unite and net returns.

The treatments of the experiment were arranged in a split plot design with three replications, planting methods were assigned at random to the main plots and intercropping patterns occupied randomly of the sub plots. The preceding crop was maize in the two growing seasons. The treatments were as follows:

\section{I-Three planting methods:}

1 -Growing on flat soil (without ridges), planting wheat in rows $(20 \mathrm{~cm}$ apart) and onion was transplanted among rows of wheat at $7 \mathrm{~cm}$ distance $\left(\mathrm{M}_{1}\right)$.

2-Wheat grown on ridges $(60 \mathrm{~cm}$ apart) on top and the northern side of ridge and onion transplanted on the southern side of the same ridge at $7 \mathrm{~cm}$ distance $\left(\mathrm{M}_{2}\right)$.

3 - Wheat grown on wide ridges $(120 \mathrm{~cm}$ apart) at 4 rows and onion transplanted on the two sides of the same ridge at $7 \mathrm{~cm}$ distance $\left(\mathrm{M}_{3}\right)$.

\section{II-Intercropping systems were as follow.}

$1-! 00 \%$ wheat $+50 \%$ green onion (G. onion) was harvested as a vegetable crop.

$2-100 \%$ wheat $+50 \%$ full mature onion (D. onion) was harvested at maturity crop.

3-Grwoing onion (G. onion) in pure stand and harvested as a vegetable crop.

4-Growing onion (D. onion) in pure stand and harvested at maturity crop.

5 -wheat in pure stand.

The pure stand of wheat and onion as well as the intercropping treatments were fertilized according to the recommended doses of each crop as recommended by the Ministry of Agriculture and Land Reclamation in order to optimize the yield of each crop. All plots received phosphoric fertilizer in the form of super phosphate $\left(15.5 \% \quad \mathrm{P}_{2} \mathrm{O}_{5}\right)$ during land preparation. Potassium sulphate $\left(48 \% \mathrm{~K}_{2} \mathrm{O}\right)$ was added before the first irrigation. Nitrogen fertilizer in the form of urea $(46.5 \% \mathrm{~N})$ was applied in two equal doses, before the first and second irrigation. 
The soil texture of the experimental site was clay, having a physical composition of: $53.33 \%$ clay, $30.44 \%$ silt, $16.24 \%$ sand and $1.53 \%$ organic matter. The soil chemical analysis was: $\mathrm{Ph} 7.94$, available $\mathrm{N}=31.52 \mathrm{mg} / \mathrm{kg}$, available $\mathrm{P}=22.49 \mathrm{mg} / \mathrm{kg}$ and available $\mathrm{K}=262 \mathrm{mg} / \mathrm{kg}$, this data were average of the two seasons.

Mean maximum temperature during growing seasons (Jan., Feb., Mar., Apr. and May) were $23.23,27.33,33.23,36.63$ and $38.50^{\circ} \mathrm{C}$, respectively. While the mean minimum temperature were $6.24,6.54,9.05,10.13$ and $10.99^{\circ} \mathrm{C}$ respectively. The average relative humidity (\%) (Jan., Feb., Mar., Apr. and May) were 74, 76, 67, 65 and 65 during the two cropping seasons, respectively.

Wheat was seeded at $20^{\text {th }}$ and $15^{\text {th }}$ November whereas, onion was transplanted at $25^{\text {th }}$ and $20^{\text {th }}$ December during the two studied seasons, respectively.

The normal cultural practices of sowing for both crops, as well as the routine spray for weeds were applied before transplanting the onion. Green onion was harvested at $21^{\text {st }}$ and $15^{\text {th }}$ March while, full mature onion was harvested at $27^{\text {th }}$ and $30^{\text {th }}$ April in addition, wheat was harvested at the first of May in the two seasons, respectively. Wheat cv. was Sakha 94 and onion cv. was Red variety.

Plot area was $14.40 \mathrm{~m}^{2}$ (4.80 m width $\times 3 \mathrm{~m}$ long). At harvest time of the two crops, the following data were recorded:

Wheat: Sample of ten plants was chosen at random from each sub plot to estimate, plant height $(\mathrm{cm})$, Spike length $(\mathrm{cm})$. Number of spikes $/ \mathrm{m}^{2}, 1000$-grain weight $(\mathrm{g})$ and grain weight $/ \mathrm{m}^{2}(\mathrm{~g})$, while grain yield (ardab) and straw yield (ton / fed) were estimated from the whole plot.

Onion: Green onion was estimated from sample of ten plants chosen at random from each sub plot to determine plant length $(\mathrm{cm})$, number of leaves /plant, weight of plant $(\mathrm{g})$ and green onion yield (ton/fed) was estimated from whole area of each sub plot. As for full mature onion was estimated from sample of ten plants from each sub plot determine, diameter of bulb $(\mathrm{cm})$, weight of bulb $(\mathrm{g})$, weight of bulbs $\left(\mathrm{g} / \mathrm{m}^{2}\right)$ and total yield of bulb (ton/fed) was estimated from whole plot.

Land Equivalent Ratio $($ LER) = yab/yaa + yba/ybb was calculated according to Willey (1979). Relative Crowding Coefficient (K),

$$
\mathrm{Kab}=\mathrm{Yab} \times \mathrm{Zba} /(\mathrm{Yaa}-\mathrm{yab}) \times \mathrm{Zab} . \mathrm{Kba}=\mathrm{Yba} \times \mathrm{Zab} /(\mathrm{Ybb}-\mathrm{Yba}) \times \mathrm{Zba} . \mathrm{K}=
$$

Kab x Kba, according to Dewit (1960) and Aggressivty(A), Aa=Yab/Yaa x Zab Yba/YbbxZba. $A b=Y b a / Y b b \times Z b a)-Y a b / Y a a x Z a b, \quad$ according to Mc-Gilchrist (1965).

Where:

Yaa $=$ yield of component (a) in pure stand .

Ybb = yield of component (b) in pure stand.

Yab = yield of component (a) in intercrop with component (b).

Yba = yield of component (b) in intercrop with component (a).

$\mathrm{Zab}=$ the proportion of component $(a)$ in the mixture.

$\mathrm{Zba}=$ the proportion of component $(\mathrm{b})$ in the mixture. 
Net returns: $=$ Gross of revenue - cost production, the total income for each crop was calculated in Egyptian pounds per feddan at the local market prices of LE 540 and 570 per ardab of grains, LE 1400 per ton of straw of wheat, LE 6.25 per kg green onion and LE 2.50 per $\mathrm{kg}$ full mature onion through the two studied seasons, respectively.

Statistical analysis of variance (ANOVA) was carried out using split plot design with three replications, growing systems were assigned at random to the main plots and intercropping patterns occupied the sub plots. The analysis of the two seasons was calculated according to (Snedecor and Cochran, 1967).The LSD value for mean comparison was calculated only if the general treatment $F$ test was significant at $5 \%$ or $\mathrm{p} \leq 0.05$ was considered to effects among treatments.

\section{RESULTS AND DISCUSSION}

\section{Wheat:}

\section{1-Effect of planting methods on wheat.}

Data presented in (Table1) show that planting methods had no significant effect on plant height, grain weight $/ \mathrm{m}^{2}$, grain yield/fed and straw yield /fed in the two studied seasons, while 1000 grain weight was significantly affected by planting methods (in 2018/19 season only) the highest 1000 grain weight $(56.87 \mathrm{~g})$ was recorded under planting method $\left(M_{1}\right)$ while, the lowest 1000 grain weight $(52.61 \mathrm{~g})$ was observed under planting method $\left(\mathrm{M}_{2}\right)$. On the other hand, each of spike length, and number of spike/ $\mathrm{m}^{2}$ were significantly affected by planting methods in the two studied seasons, the highest spike length $(15.29$ and $15.47 \mathrm{~cm}$ ) were recorded in planting wheat on wide ridges. 120 $\mathrm{cm}$ apart $\left(\mathrm{M}_{3}\right)$ while, the highest number of spikes $/ \mathrm{m}^{2}(225.78,230.08$ and 234.78 , 226.99 spike) were obtained under planting methods $\left(\mathrm{M}_{1}\right.$ and $\left.\mathrm{M}_{2}\right)$ during the two seasons, respectively. Hassan et al. (2003) found that, methods of sowing were statistically significant for plant height, No. of grains/spike, 1000- grain weight and biological yield. 
Table (1). Effect of planting methods and intercropping green and full mature onion with wheat on wheat in 2017/2018 and 2018/2019 seasons

\begin{tabular}{|c|c|c|c|c|c|c|c|}
\hline Treatments & $\begin{array}{c}\text { Plant } \\
\text { height }(\mathrm{cm})\end{array}$ & $\begin{array}{c}\text { Spike } \\
\text { length }(\mathrm{cm})\end{array}$ & $\begin{array}{l}\text { Number of } \\
\text { spike/m² }\end{array}$ & $\begin{array}{l}1000 \text { grain } \\
\text { weight(g) }\end{array}$ & $\begin{array}{c}\text { Grain } \\
\text { weight } \\
/ \mathrm{m}^{2}(\mathrm{~g})\end{array}$ & $\begin{array}{l}\text { Grain yield } \\
\text { (ardab/fed) }\end{array}$ & $\begin{array}{c}\text { Straw } \\
\text { yield } \\
\text { (ton/fed) }\end{array}$ \\
\hline & \multicolumn{7}{|c|}{$2017 / 2018$} \\
\hline M1 & 101.13 & 13.01 & 225.78 & 56.11 & 764.45 & 21.81 & 4.335 \\
\hline M2 & 99.16 & 14.23 & 230.08 & 55.10 & 775.20 & 22.11 & 3.461 \\
\hline M3 & 101.73 & 15.29 & 196.67 & 54.56 & 760.01 & 21.58 & 3.707 \\
\hline L. S. D. at $5 \%$ & NS & 1.13 & 19.67 & NS & NS & NS & NS \\
\hline W.+G. onion & 100.02 & 14.25 & 216.56 & 55.29 & 767.61 & 21.91 & 3.691 \\
\hline W.+D. onion & 100.01 & 14.04 & 215.44 & 54.99 & 760.84 & 21.28 & 3.866 \\
\hline W. pure & 305.93 & 15.25 & 223.85 & 55.48 & 771.20 & 22.28 & 3.946 \\
\hline L. S. D. at $5 \%$ & NS & NS & NS & NS & NS & NS & NS \\
\hline \multirow[t]{2}{*}{ Interaction } & NS & NS & NS & NS & NS & NS & NS \\
\hline & \multicolumn{7}{|c|}{$2018 / 2019$} \\
\hline M1 & 99.18 & 12.71 & 234.78 & 56.87 & 786.77 & 22.43 & 4.099 \\
\hline M2 & 95.27 & 13.68 & 226.99 & 52.61 & 767.48 & 21.89 & 3.756 \\
\hline M3 & 97.14 & 15.47 & 195.56 & 54.74 & 756.66 & 21.59 & 3.512 \\
\hline L. S. D. at $5 \%$ & NS & 1.21 & 21.73 & 1.44 & NS & NS & NS \\
\hline W.+G. onion & 94.44 & 14.13 & 219.83 & 53.85 & 769.61 & 21.15 & 3.788 \\
\hline W.+D. onion & 99.71 & 13.67 & 219.89 & 55.71 & 760.07 & 21.39 & 3.720 \\
\hline W. pure & 97.45 & 14.05 & 217.61 & 54.67 & 781.34 & 22.38 & 3.859 \\
\hline L. S. D. at $5 \%$ & 2.76 & NS & NS & NS & NS & NS & NS \\
\hline Interaction & NS & NS & NS & NS & NS & NS & NS \\
\hline
\end{tabular}

$\mathrm{M}=$ Planting method

W. $=$ Wheat $\quad$. onion $=$ Green onion

D. onion = Dry onion

\section{2-Effect of intercropping on wheat.}

Data in Table (1) showed the effect of intercropping onion with wheat on wheat yield and yield components. Data clearly indicated that onion was weak in its competition with wheat, differences between treatments failed to reach the $5 \%$ level of significance and had no significant effect on all studied characters of wheat, except on plant height in 2018/19 season, which was significantly affected by intercropping onion with wheat. The tallest plants were recorded by intercropping onion with wheat. AbouHussein et al. (2005) confirmed that the intercropping (green onion) did not interfere with the growth and yield of the main crop. Mahdi et al. (2011) studied intercropping onion and garlic with broad bean (Vicia faba L.), they found that it did not showed the best intercropping.

3-Effect of interaction between planting methods and intercropping green and full mature onion with wheat on wheat.

Data in Table (1) showed that, the interaction between planting methods and intercropping systems were not significant effect in the two studied seasons, Hossain et al. (2003) found that, onion as first intercrop also does not show any adverse effect on sugarcane yield and growth. 
Onion:

a-Green onion

1-Effect of planting methods.

Results shown in Table (2) indicated that, all studied characters of green onion were significantly affected by planting methods during 2017/18 and 2018/19 seasons. Data show that, growing onion on wide ridges (120 cm apart)

Table (2). Effect of planting methods and intercropping onion with wheat on green onion in $2015 / 2016$ and $2016 / 2017$ seasons

\begin{tabular}{lcccccccc}
\hline \multirow{2}{*}{ Treatments } & \multicolumn{2}{c}{ Plant length $\mathbf{( c m )}$} & \multicolumn{2}{c}{$\begin{array}{c}\text { No. of } \\
\text { leaves/plant }\end{array}$} & $\begin{array}{c}\text { Weight of plant } \\
(\mathbf{g})\end{array}$ & $\begin{array}{c}\text { Weight of green } \\
\text { onion (ton/fed) }\end{array}$ \\
\cline { 2 - 9 } & $\mathbf{2 0 1 7 / 1 8}$ & $\mathbf{2 0 1 8 / 1 9}$ & $\mathbf{2 0 1 7 / 1 8}$ & $\mathbf{2 0 1 8 / 1 9}$ & $\mathbf{2 0 1 7 / 1 8}$ & $\mathbf{2 0 1 8 / 1 9}$ & $\mathbf{2 0 1 7 / 1 8}$ & $\mathbf{2 0 1 8 / 1 9}$ \\
\hline M1 & 24.83 & 24.01 & 8.93 & 8.27 & 15.39 & 15.97 & 2.825 & 2.839 \\
M2 & 40.95 & 45.17 & 12.38 & 11.62 & 21.84 & 21.49 & 3.962 & 3.895 \\
M3 & 40.67 & 48.51 & 13.17 & 12.30 & 23.79 & 24.44 & 3.909 & 4.019 \\
L.S.D. at 5\% & 5.12 & 12.04 & 2.11 & 0.92 & 4.99 & 5.65 & 0.560 & 0.970 \\
W. +G. onion & 30.86 & 36.22 & 9.29 & 8.42 & 11.52 & 12.86 & 0.983 & 1.153 \\
G. onion pure & 40.11 & 42.22 & 13.71 & 13.03 & 29.16 & 28.41 & 6.148 & 6.004 \\
L.S.D. at 5\% & 4.32 & NS & 1.41 & 1.06 & 1.98 & 3.74 & 0.290 & 0.600 \\
Interaction & 7.48 & NS & 2.45 & 1.83 & 3.47 & 6.48 & 0.520 & NS \\
\hline
\end{tabular}

$\mathrm{M}=$ Planting method $\mathrm{W} .=$ Wheat $\quad \mathrm{G}$. onion $=$ Green onion

or (60 cm apart) recorded high yields more than growing on flat soil $\left(\mathrm{M}_{1}\right)$, which gave less yield. This was true for all studied characters of green onion. The data in Table (2) indicated that growing onion on wide ridges $\left(\mathrm{M}_{3}\right)$ recorded the highest values of green onion yield (3.909 and 4.019 ton/fed) were recorded in the two growing seasons and achieved an increase about (1.084 and1.180 ton/fed) more than growing onion on flat soil $\left(M_{1}\right)$. Mohd et al. (2015) reported that combined effect of spacing and fertilizer had significant effect on yield and its attributes of onion. Sarker et al. (2017) revealed that planting method and management practices had significant impact on yield and yield attributes of onion and among the treatments. They found that, the highest yield $14.42 \mathrm{t}$ $\mathrm{ha}^{-1}$ in 2014-15 and $12.57 \mathrm{t} \mathrm{ha}^{-1}$ in 2015-16 was recorded from Spices Research Centre (SRC) recommended practice. The lowest yield $8.05 \mathrm{t} \mathrm{ha}^{-1}$ in 2014-15 and $7.66 \mathrm{t} \mathrm{ha}^{-1}$ in 2015-16 was recorded from Flat method + Farmer's practice. So that farmers of Faridpur region of Bangladesh are advised to adopt SRC recommended practice with raised bed method for increasing their annual average onion production.

\section{2-Effect of intercropping.}

With respect to green onion the same trend was indicated where, the pure culture was superior to the intercropping in all studied characters as shown in Table (2). AbouHussein et al. (2005) reported that, growth characteristics of green onion were significantly affected by intercropping where average plant length, number of leaves and bulb diameter of green onion head tended to be lower than the sole green onion, respectively. 


\section{3-Effect of interaction on green onion.}

As shown in Table (3) data obtained indicated that, interaction between planting methods and intercropping had significant effect on all studied characters. Plant length and weight of green onion ton /fed were significantly affected by interaction in 2017/2018 season only, the highest green onion (6.874 ton/fed) was recorded when growing onion on ridges $(60 \mathrm{~cm}$ apart) in pure stand, followed by $(1.492$ ton/fed) when green onion was planted on the two sides of ridges $\left\{120 \mathrm{~cm}\right.$ apart $\left.\left(\mathrm{M}_{3}\right)\right\}$ under intercropping condition with wheat. Abou-Hussein et al. (2005) reported that, growth characteristics of green onion were significantly affected by intercropping where average plant length, number of leaves and bulb diameter of green onion head tended to be lower than the sole green onion, respectively.

Table (3). Effect of interaction between planting methods and intercropping onion with wheat on green onion in 2015/2016 and 2016/2017 seasons

\begin{tabular}{|c|c|c|c|c|c|c|c|c|c|}
\hline \multirow{2}{*}{\multicolumn{2}{|c|}{ Treatments }} & \multicolumn{2}{|c|}{ Plant length $(\mathrm{cm})$} & \multicolumn{2}{|c|}{$\begin{array}{c}\text { No. of } \\
\text { leaves/plant }\end{array}$} & \multicolumn{2}{|c|}{$\begin{array}{l}\text { Weight of } \\
\text { plant(gm) }\end{array}$} & \multicolumn{2}{|c|}{$\begin{array}{l}\text { Weight of green } \\
\text { onion ton/fed }\end{array}$} \\
\hline & & $2017 / 18$ & $2018 / 19$ & $2017 / 18$ & $2018 / 19$ & $2017 / 18$ & $2018 / 19$ & $2017 / 18$ & $2018 / 19$ \\
\hline \multirow{2}{*}{ M1 } & W. +G. onion & 15.33 & 16.67 & 5.67 & 5.01 & 4.83 & 5.57 & 0.405 & 0.470 \\
\hline & G. onion pure & 34.33 & 31.33 & 12.20 & 11.53 & 25.95 & 26.37 & 5.245 & 5.208 \\
\hline \multirow[b]{2}{*}{ M2 } & W. +G. onion & 37.23 & 41.01 & 9.89 & 9.01 & 11.99 & 12.50 & 1.051 & 1.265 \\
\hline & G. onion pure & 44.67 & 49.33 & 14.90 & 14.23 & 31.69 & 30.47 & 6.874 & 6.491 \\
\hline & W. +G. onion & 40.01 & 51.00 & 12.33 & 11.27 & 17.74 & 20.51 & 1.492 & 1.723 \\
\hline & G. onion pure & 41.33 & 46.00 & 14.01 & 13.34 & 29.84 & 28.38 & 6.326 & 6.314 \\
\hline & L. S. D. at $5 \%$ & 7.48 & NS & 2.45 & 1.83 & 3.47 & 6.48 & 0.510 & NS \\
\hline \multicolumn{2}{|c|}{$\mathrm{M}=$ Planting method } & $\mathrm{W} .=\mathrm{W}$ & $\mathrm{t}$. & $n=G$ & onion & & & & \\
\hline
\end{tabular}

Results in Table (4) indicated that, all studied characters of dry onion were significantly affected by planting methods. It indicated that growing onion on the two sides of wide ridges $\left\{120 \mathrm{~cm}\right.$ apart $\left.\left(\mathrm{M}_{3}\right)\right\}$ recorded the highest values in most studied characters and recorded (7.828 and 7.801 ton/fed) of bulb yield /fed in the two growing seasons. Planting methods on ridges $\left\{120 \mathrm{~cm}\right.$ apart $\left.\left(\mathrm{M}_{3}\right)\right\}$

Table (4). Effect of planting methods and intercropping onion with wheat on full mature onion in 2015/2016 and 2016/2017 seasons

\begin{tabular}{lcccccccc}
\hline \multirow{2}{*}{ Treatments } & \multicolumn{2}{c}{$\begin{array}{c}\text { Diameter of bulb } \\
(\mathbf{c m})\end{array}$} & \multicolumn{2}{c}{ Weight of bulb (g) } & $\begin{array}{c}\text { Weight of blub (kg } \\
\text { / } \mathbf{2} \text { ) }\end{array}$ & \multicolumn{2}{c}{$\begin{array}{c}\text { Weight of bulb } \\
\text { (ton/fed) }\end{array}$} \\
\cline { 2 - 9 } & $\mathbf{2 0 1 7 / 1 8}$ & $\mathbf{2 0 1 8 / 1 9}$ & $\mathbf{2 0 1 7 / 1 8}$ & $\mathbf{2 0 1 8 / 1 9}$ & $\mathbf{2 0 1 7 / 1 8}$ & $\mathbf{2 0 1 8 / 1 9}$ & $\mathbf{2 0 1 7 / 1 8}$ & $\mathbf{2 0 1 8 / 1 9}$ \\
\hline M1 & 3.13 & 3.36 & 29.60 & 30.79 & 1.289 & 1.224 & 5.738 & 5.858 \\
M2 & 3.94 & 4.07 & 44.67 & 44.36 & 1.778 & 1.682 & 7.479 & 7.536 \\
M3 & 3.92 & 4.21 & 47.83 & 48.84 & 1.798 & 1.686 & 7.828 & 7.801 \\
L.S.D. at 5\% & 0.62 & 0.75 & 5.29 & 5.04 & 0.344 & 0.287 & 1.140 & 0.530 \\
W. +D. onion & 2.75 & 3.20 & 21.31 & 23.37 & 0.491 & 0.534 & 2.153 & 2.292 \\
D. onion pure & 4.57 & 4.55 & 60.09 & 59.29 & 2.754 & 2.527 & 11.877 & 11.838 \\
L.S.D. at 5\% & 0.48 & 0.47 & 4.80 & 6.83 & 0.210 & 0.196 & 0.990 & 0.420 \\
Interaction & NS & 0.82 & 8.31 & NS & NS & NS & 1.400 & 0.720 \\
\hline
\end{tabular}

$\mathrm{M}=$ Planting method $\quad \mathrm{W} .=$ Wheat $\quad$ D. onion = Dry onion (full mature onion) 
achieved an increase in bulb yield about (2.090 and 1.943 ton/fed) more than growing onion on flat soil $\left\{\right.$ without ridges $\left.\left(\mathrm{M}_{1}\right)\right\}$ in the two studied seasons. Sarker et al. (2017) reported that planting method had significant impact on yield and yield attributes of onion and among the treatments found that, the highest yield was recorded from Spices Research Centre (SRC) recommended practice. The lowest yield was recorded from Flat method + Farmer's practice.

\section{2-Effect of intercropping.}

Data in (Table 4) showed that, most studied characters of dry onion were significantly affected by intercropping and pure culture recorded the highest values in all studied characters where, the pure onion recorded an increase of about in bulb yield (9.724 and 9.546 ton/fed) than the intercropping during the two studied seasons. AbouKeriasha et al. (2013) showed that all studied characters of onion were significant when intercropped with faba bean. The yield and yield components of intercropped crops (onion and wheat) were decreased when intercropped with faba bean. The reduction in bulb yield of onion was 3.0 and $4.4 \%$.

\section{3-Effect of interaction.}

In Table (5), data obtained showed that, interaction between planting methods and intercropping had significant effect on most studied characters of full mature onion. Diameter of bulb was significantly affected by interaction in $2018 / 2019$ season only, the highest value $(4.96 \mathrm{~cm})$ was obtained when onion was grown on ridges $(60 \mathrm{~cm}$ apart) in pure stand, followed by $(3.93 \mathrm{~cm} / \mathrm{bulb})$ obtained when onion was grown on two sides of ridges $(120 \mathrm{~cm}$ apart) under

Table (5). Effect of interaction between planting methods and intercropping onion with wheat on full mature onion in 2015/2016 and 2016/2017 seasons

\begin{tabular}{|c|c|c|c|c|c|c|c|c|c|}
\hline \multirow{2}{*}{\multicolumn{2}{|c|}{ Treatments }} & \multicolumn{2}{|c|}{$\begin{array}{l}\text { Diameter of } \\
\text { bulb }(\mathrm{cm})\end{array}$} & \multicolumn{2}{|c|}{$\begin{array}{l}\text { Weight of bulb } \\
(\mathrm{g})\end{array}$} & \multicolumn{3}{|c|}{ Weight of blub $\left(\mathrm{kg} / \mathrm{m}^{2}\right)$} & \multirow{2}{*}{$\begin{array}{c}\begin{array}{c}\text { Weight of } \\
\text { bulb (ton/fed) }\end{array} \\
2018 / 19\end{array}$} \\
\hline & & $2017 / 18$ & $2018 / 19$ & $2017 / 18$ & $2018 / 19$ & $2017 / 18$ & $2018 / 19$ & $2017 / 18$ & \\
\hline \multirow{2}{*}{ M1 } & W. +D. onion & 2.20 & 2.51 & 7.98 & 8.57 & 0.188 & 0.198 & 0.798 & 0.835 \\
\hline & D. onion pure & \multicolumn{2}{|c|}{4.07} & 4.23 & 51.23 & 53.01 & 2.390 & 2.250 & 10.67810 .880 \\
\hline \multirow{2}{*}{ M2 } & W. + D. onion & \multicolumn{2}{|c|}{2.83} & 3.17 & 22.33 & 25.52 & 0.546 & 0.602 & $2.392 \quad 2.271$ \\
\hline & D. onion pure & \multicolumn{2}{|c|}{5.40} & 4.96 & 67.01 & 63.19 & 3.010 & 2.762 & 12.56612 .501 \\
\hline \multirow{3}{*}{ M3 } & W. +D. onion & \multicolumn{2}{|c|}{3.23} & 3.93 & 33.63 & 36.02 & 0.735 & 0.803 & 3.268 \\
\hline & D. onion pure & 4.60 & 4.47 & 62.03 & 61.67 & 2.861 & 2.569 & 12.387 & 12.133 \\
\hline & L. S. D. at $5 \%$ & NS & 0.82 & 8.31 & NS & NS & NS & 1.400 & 0.720 \\
\hline
\end{tabular}

$\mathrm{M}=$ Planting method

W. $=$ Wheat

D. onion = Dry onion (full mature onion)

intercropping condition but, weight of bulb was significantly affected by interaction in $2017 / 2018$ season only and take the same trend of bulb diameter. Yield of bulb ton/fed was significantly affected by interaction the highest values (12.566 and 12.501 ton/fed) were recorded when onion was grown on ridges $(60 \mathrm{~cm}$ apart) in pure stand followed by (3.268 and 3.469 ton/fed) when onion was grown on the two sides of ridges $\{120 \mathrm{~cm}$ apart $\left.\left(\mathrm{M}_{3}\right)\right\}$ under intercropping condition with wheat in the two studied seasons. Kanwar and Ishfaq Akbar (2013) found superior of bulb diameter when onion was transplanted on both sides of ridges or in middle of ridges. Hybrid Rosy recorded statistically superior bulb diameter in middle of ridges. 


\section{4-Effcet of planting methods and intercropping green and full mature onion with wheat on relationships and net returns:}

Relationships. Data in Table (6) indicate clearly that, relative yield of onion increased with wheat when grown on wide ridges $(120 \mathrm{~cm}$ apart) than the two other growing methods. The highest values of LER and $\mathrm{K}$ were obtained in the intercrop combinations which included growing the two species (wheat and onion) on wide ridges $(120 \mathrm{~cm}$ apart) and intercropped green onion with wheat. From another angle, data evident that the increase in land use efficiency resulted from growing the two species on wide ridges (120 apart) which estimated by $21.30,19.10$ and $26.80,23.30 \%$ with intercropping green and dry onion compared with pure stand in the two studied seasons, respectively. Zen El-Dein (2016) studied planting methods and NPK fertilizer on intercropping onion with wheat, he found that the highest LER was obtained when both crops were grown on width ridges $(120 \mathrm{~cm}$ apart) and received NPK fertilizer.

Data in Table (6) indicated that, aggressivity on onion was increased by intercropping the two crops on flat soil (wheat seeded at rows and onion transplanting between rows of wheat), but it was low by intercropping onion with wheat on wide ridges (120 cm apart). In all intercropping treatments, wheat was the dominate and onion was the dominated. Abou-Hussein et al. (2005) indicated that, green bean and onion had positive effect on land use efficiency and available growth resource. Mahdi et al. (2011) indicated that, planting broad bean with onion and garlic was the best manner for production per unit area in agricultural aims, comparing with monoculture bean alone, but the intercropping plants may require more effort and service than a monoculture crop. Abou-Keriasha et al. (2013) reported that, the highest values of land equivalent ratio "LER" (1.59) was observed when was inoculated faba bean seeds with bacteria before sown and intercropping on onion. While, the values of competitive ratio (CR) of faba bean were greater when intercropping on onion than those intercropping on wheat.

Net returns. Data in Table (7) showed that, the lowest net returns (LE 13969.90 and $13307.50 /$ fed) were obtained when growing wheat in monoculture crop with growing planting method $\left(\mathrm{M}_{3}\right)$. The highest net returns (LE 20617.50 and $21675.60 /$ fed) were obtained when intercropped green onion with wheat on wide ridges $\{120 \mathrm{~cm}$ apart (M3)\} compared with wheat in pure stand in the two growing seasons. All intercropping systems recorded net returns more than wheat in pure stand and surpassed the unity. Green and dry onion had net returns (LE 31872.90, 30615.80 and 22245.30, $21774.40 / f e d)$ when grown in pure stand in two seasons, respectively. Badraoui et al. (2003) found that, intercropping improves revenue and decreases costs. Khan et al. (2012) reported that, wheat and canola intercropping were more productive and economically profitable than all other inter-and sole crops. Abou-Keriasha et al. (2013) reported that, the highest value of monetary advantage index 'MAl' (3636.477) was observed when faba bean intercropping on onion. While, the values of faba bean were greater when intercropping on onion than those intercropping on wheat. 
Table (6). Effect of planting methods and intercropping, green and full mature onion with wheat on relationships (2016/2016 and 2016/2017 seasons)

\begin{tabular}{|c|c|c|c|c|c|c|c|c|c|c|c|c|c|c|c|c|c|c|c|c|}
\hline \multirow{3}{*}{$\mathrm{T}$. } & \multicolumn{7}{|c|}{ Land equivalent ratio (LER) } & \multicolumn{7}{|c|}{ Relative crowding Coefficient(K) } & \multicolumn{6}{|c|}{ Aggressivty (Agg) } \\
\hline & \multicolumn{3}{|c|}{ W.+ green onion } & \multicolumn{3}{|c|}{ W.+ yield onion } & \multirow{2}{*}{ Average } & \multicolumn{3}{|c|}{ W.+ green onion } & \multicolumn{3}{|c|}{ W.+ yield onion } & \multirow{2}{*}{ Average } & \multicolumn{2}{|c|}{$\begin{array}{l}\text { W.+ green } \\
\text { onion }\end{array}$} & \multicolumn{2}{|c|}{ W.+ dry onion } & \multicolumn{2}{|c|}{ Average } \\
\hline & Lw & Lo & LER & Lw & Lo & LER & & $\mathrm{Kw}$ & Ko & $\mathrm{K}$ & $\mathrm{Kw}$ & Ko & $\mathrm{K}$ & & Aw & Ao & Aw & Ao & Aw & Ao \\
\hline & \multicolumn{20}{|c|}{ 2017/2018 } \\
\hline $\mathrm{M}_{1}$ & 0.963 & 0.077 & 1.040 & 0.946 & 0.075 & 1.021 & 1.031 & 13.167 & 0.167 & 2.204 & 5.739 & 0.162 & 0.930 & 1.567 & +1.226 & -1.226 & +1.207 & -1.207 & +1.217 & -1.217 \\
\hline $\mathrm{M}_{2}$ & 0.996 & 0.182 & 1.178 & 0.974 & 0.190 & 1.164 & 1.171 & 120.55 & 0.445 & 53.640 & 18.946 & 0.470 & 8.909 & 31.275 & +0.958 & -0.958 & +0.899 & -0.899 & +0.927 & -0.927 \\
\hline $\mathrm{M}_{3}$ & 0.977 & 0.236 & 1.213 & 0.927 & 0.264 & 1.191 & 1.202 & 21.149 & 0.617 & 13.055 & 6.329 & 0.418 & 2.642 & 7.849 & +0.765 & -0.765 & +0.605 & -0.605 & +0.685 & -0.685 \\
\hline Average & 0.979 & 0.165 & 1.144 & 0.949 & 0.176 & 1.125 & 1.135 & 51.622 & 0.411 & 22.966 & 10.338 & 0.350 & 4.160 & 13.564 & +0.983 & -0.983 & +0.904 & -0.904 & +0.943 & -0.943 \\
\hline \multirow[t]{2}{*}{ L.S.D.5\% } & \multicolumn{2}{|c|}{$M=N S$} & \multicolumn{2}{|c|}{ In. $=0.015$} & \multicolumn{3}{|c|}{$\mathrm{M} \times \ln .=\mathrm{NS}$} & \multicolumn{2}{|r|}{$M=N S$} & \multicolumn{2}{|c|}{ In. $=$ NS } & \multicolumn{3}{|c|}{$M \times \ln .=N S$} & \multicolumn{2}{|c|}{$M=N S$} & \multicolumn{2}{|c|}{ In. $=N S$} & \multicolumn{2}{|c|}{$\mathrm{M} \times \ln .=\mathrm{NS}$} \\
\hline & \multicolumn{20}{|c|}{$2018 / 2019$} \\
\hline $\mathrm{M}_{1}$ & 0.975 & 0.070 & 1.045 & 0.936 & 0.077 & 1.013 & 1.029 & 19.371 & 0.193 & 3.843 & 7.340 & 0.166 & 1.218 & 2.531 & +1.204 & -1.204 & +1.186 & -1.186 & +1.195 & -1.195 \\
\hline $\mathrm{M}_{2}$ & 0.990 & 0.195 & 1.185 & 0.969 & 0.206 & 1.175 & 1.180 & 47.136 & 0.484 & 22.820 & 15.37 & 0.518 & 7.964 & 15.392 & +0.908 & -0.908 & +0.844 & -0.844 & +0.876 & -0.876 \\
\hline $\mathrm{M}_{3}$ & 0.995 & 0.273 & 1.268 & 0.947 & 0.286 & 1.233 & 1.251 & 98.000 & 0.757 & 74.186 & 8.971 & 0.801 & 7.184 & 40.685 & +0.680 & -0.680 & +0.569 & -0.569 & +0.625 & -0.625 \\
\hline Average & 0.987 & 0.179 & 1.166 & 0.951 & 0.190 & 1.141 & 1.153 & 54.836 & 0.478 & 33.616 & 10.560 & 0.495 & 5.455 & 19.536 & +0.931 & -0.931 & +0.866 & -0.866 & +0.899 & -0.899 \\
\hline L.S.D. $5 \%$ & $\mathrm{~N}$ & $M=0.14$ & & In. $=\mathrm{NS}$ & & $\mathrm{x} \ln .=\mathrm{N}$ & & & $=4.571$ & & In. $=N S$ & & $M \times \ln .=$ & $=\mathrm{NS}$ & $M=0$ & 0.263 & $\ln .=N$ & & $M \times I n$. & $=\mathrm{NS}$ \\
\hline
\end{tabular}


J. Adv. Agric. Res. (Fac. Agric. Saba Basha)

Table (7). Economics of various intercropping green and full mature onion with wheat

\begin{tabular}{|c|c|c|c|c|c|c|c|c|c|c|c|c|c|c|c|c|c|c|c|c|c|}
\hline \multirow{4}{*}{ Tr. } & \multicolumn{8}{|c|}{ Wheat } & \multirow{2}{*}{\multicolumn{4}{|c|}{ Onion ton/fed }} & \multirow{3}{*}{$\begin{array}{c}\text { Cost of } \\
\text { production } \\
\text { (E.L.) }\end{array}$} & \multirow{2}{*}{\multicolumn{4}{|c|}{ Gross of revenue (E.L.) }} & \multirow{2}{*}{\multicolumn{4}{|c|}{ Net returns (E.L.) }} \\
\hline & \multicolumn{4}{|c|}{ Grain } & \multicolumn{4}{|c|}{ Straw } & & & & & & & & & & & & & \\
\hline & $\mathrm{M}_{1}$ & $\mathrm{M}_{2}$ & $\mathrm{M}_{3}$ & Average & Average & $\mathrm{M}_{2}$ & $\mathrm{M}_{3}$ & Average & $\mathrm{M}_{1}$ & $\mathrm{M}_{2}$ & $\mathrm{M}_{3}$ & Average & & $\mathrm{M}_{1}$ & $\mathrm{M}_{2}$ & $\mathrm{M}_{3}$ & Average & $\mathrm{M}_{1}$ & $\mathrm{M}_{2}$ & $\mathrm{M}_{3}$ & Average \\
\hline & \multicolumn{21}{|c|}{$2017 / 2018$} \\
\hline$w_{.}+g$ & 22.12 & 21.70 & 19.88 & 22.23 & 4.152 & 3.467 & 3.453 & 3.691 & 0.405 & 1.051 & 1.492 & 1.049 & 4875 & 20958.3 & 23793.5 & 25492.5 & 23414.8 & 16083.3 & 18918.5 & 20617.5 & 18539.8 \\
\hline W.+d. & 21.72 & 21.23 & 18.86 & 20.60 & 4.396 & 3.402 & 3.801 & 3.866 & 0.798 & 2.392 & 3.268 & 2.153 & 5125 & 20532.8 & 22844.7 & 24245.4 & 22541.0 & 15407.8 & 17719.7 & 19120.4 & 17416.0 \\
\hline $\begin{array}{l}\text { W. } \\
\text { pure }\end{array}$ & 22.96 & 21.79 & 20.35 & 21.70 & 4.457 & 3.514 & 3.867 & 3.946 & ----- & --- & ------- & ----- & 3051 & 19338.4 & 17341.8 & 17020.9 & 17900.4 & 16287.4 & 14290.8 & 13969.9 & 14849.4 \\
\hline $\begin{array}{l}\text { G.o. } \\
\text { pure }\end{array}$ & ------- & ------- & ------ & ------ & ------- & ------ & ------ & ---- & 5.245 & 6.874 & 6.326 & 6.148 & 6554 & 32781.3 & 42960.4 & 39539.1 & 38426.9 & 26227.3 & 36406.4 & 32985.1 & 31872.9 \\
\hline $\begin{array}{l}\text { D.o. } \\
\text { pure }\end{array}$ & ---- & ------- & ------ & ------- & ------- & ---- & ------ & ---- & 10.678 & 12.566 & 12.387 & 11.877 & 7448 & 26695.8 & 31415.8 & 30968.3 & 29693.3 & 19247.8 & 23967.8 & 23520.3 & 22245.3 \\
\hline \multirow[t]{2}{*}{$\begin{array}{l}\text { L.S.D. } \\
5 \% \\
\end{array}$} & \multicolumn{4}{|c|}{$\begin{array}{c}\mathrm{M}=\mathrm{NS} \quad \ln .=\mathrm{NS} \\
\mathrm{M} \times \ln .=\mathrm{NS}\end{array}$} & $\mathrm{M}=\mathrm{NS}$ & $\mathrm{In} .=\mathrm{N}$ & \multicolumn{2}{|c|}{$\mathrm{M} \times \ln .=\mathrm{NS}$} & \multicolumn{4}{|c|}{$\begin{array}{c}M=0.430 \quad \ln .=0.560 \\
M \times \ln .=0.970\end{array}$} & --- & \multicolumn{4}{|c|}{$\begin{array}{c}M=1831.4 \quad \ln .=2313.4 \\
M x \ln .=4006.8\end{array}$} & \multicolumn{3}{|c|}{$\begin{array}{cc}M=1838.1 & \ln .=18 \\
M x \ln .=3252.1\end{array}$} & 777.6 \\
\hline & \multicolumn{21}{|c|}{$2018 / 2019$} \\
\hline W.+g. & 22.47 & 20.74 & 19.60 & 20.94 & 4.146 & 3.806 & 3.411 & 3.788 & 0.470 & 1.265 & 1.723 & 1.153 & 5065 & 22225.4 & 25677.1 & 26740.6 & 24881.0 & 17160.4 & 20612.1 & 21675.6 & 19816.0 \\
\hline W.+y. & 21.58 & 20.30 & 18.66 & 20.18 & 4.051 & 3.500 & 3.608 & 3.720 & 0.835 & 2.571 & 3.469 & 2.292 & 5365 & 20708.6 & 23505.5 & 25484.2 & 23232.8 & 15343.6 & 18140.5 & 20119.2 & 17867.8 \\
\hline $\begin{array}{l}\text { W. } \\
\text { pure } \\
\text { G. }\end{array}$ & 23.05 & 20.96 & 19.70 & 21.24 & 4.099 & 3.962 & 3.515 & 3.859 & ---- & ---- & ------ & ----- & 3312 & 19571.1 & 18122.3 & 16619.5 & 18104.3 & 16259.1 & 14810.3 & 13307.5 & 14792.3 \\
\hline $\begin{array}{c}\text { onion } \\
\text { pure } \\
D .\end{array}$ & ------ & ------- & ------ & ------- & ------- & ------ & ------ & ----- & 5.208 & 6.491 & 6.314 & 6.004 & 6912 & 32550.0 & 40570.8 & 39462.5 & 37527.8 & 25638.0 & 33658.8 & 32550.5 & 30615.8 \\
\hline $\begin{array}{l}\text { onion } \\
\text { pure }\end{array}$ & ----- & ----- & ---- & ----- & ----- & ------ & ----- & ----- & 10.880 & 12.500 & 12.133 & 11.838 & 7820 & 27200.0 & 31250.0 & 30333.3 & 29594.4 & 19380.0 & 23430.0 & 22513.3 & 21774.4 \\
\hline $\begin{array}{l}\text { L.S.D. } \\
5 \%\end{array}$ & $M=N S$ & $S$ In & $=N S \quad 1$ & $M x I n .=N S$ & $M=N S$ & $\ln .=\mathrm{N}$ & NS & MxIn. $=N S$ & & $\begin{aligned}=0.560 \\
\text { MxIn. }\end{aligned}$ & $\begin{aligned} & \ln .=0 . \\
&= 0.900 \\
&\end{aligned}$ & & -- & $\mathrm{M}$ & $\begin{array}{r}=2066.6 \\
\text { MxIn. }=\end{array}$ & $\begin{aligned} & \text { In. }=274 \\
&= 4758.1 \\
&\end{aligned}$ & 47.1 & & $\begin{array}{r}=2066.6 \\
\text { MxIn. }=\end{array}$ & $\begin{aligned} & \ln .=274 \\
&= 4758.1 \\
&\end{aligned}$ & \\
\hline
\end{tabular}




\section{REFERENCES}

Abou-Hussein, S.D., S.R. Salman, A.M.R., Abdel-Mawgoud and A.A. Ghonam (2005). Productivity, quality and profit of sole or intercropping green bean (PHASOLUS VALGARIS I.). Crop Journal of Agronomy 4(2): 151-155.

Abou-Keriasha, M.A.,M.A. Nadia Eisa and N.M.H. El-Waki (2013).Effects of Intercropping Faba Bean on Onion and Wheat With or Without Inoculated Bacteria on Yields of the Three Crops. Egypt. J. Agron. Vol. 35, No. 2, pp. 169 182.

Badraoui, M.M. Agbani, R. Bouabid, M. El-Gharous, M. Karrou and M. Zeraouli (2003). New recommendations for the wheat, sugar beet and sunflower cropping in the Doukkala and Gharb irrigated regions of Morocco. Proc. Regional Workshop of the International Potash Institute, Amman, PP. 113-119.

Baumann, D.T., L. Bastiaans and M.J. Kropff (2001).Competition and crop performance in a leek-celery intercropping system. Crop Sci., 41: 764-774.Dirct Link 1.

Black, C.A. (1965). Methods of soil analysis. Part1, American Society of Agronomy. Madison, Wisconsin, USA. 1572P.

Brown, J.E., W.E. Splittstoesser and J.M. Gerber (1985).Production and economic returns of vegetable intercropping systems. J. Am. Soc. Hortic. Sci., 110: 350353.

Dewit, C. T. (1960). On competition Versl. Landbouwk Onder zoek 66: 1-82.

Guvenc, I. and E. Yildirim (1999). Multiple cropping systems in vegetable production. Proceedings of the International Conference on Organic Agriculture, Jun. 21-23, Izmir, Turkey, pp: 288-296.

Hassan, G. Faiz, B. Marwat, and K.B. Nwfp (2003). Effects of planting methods and tank mixed herbicides on controlling grassy and broadleaf weeds and their effect on wheat [cv. Fakhr-e-Sarhad]. Agricultural Univ., Peshawar (Pakistan).Dept. of Weed Science.

Hossain, G.M.A, S.M. Bokhtiar, S.K. Paul and M.R. Anam (2003). Intercropping of sugarcane with onion and potato followed by sesame in paired row system.J. of Agro., 2: 85-91.

Kanwar, M. S. and P. Ishfaq Akbar (2013). Effectof planting methodson performance onion varietiesunder cold desert conditions .Sher-e-Kashmir University of Agricultural Sciences and Technology of Kashmir High Mountain Arid Agriculture Research Institute, The Biascan 8(3): 911-913.

Khan, M.B., M.Khan, M.Hussaini, M. Farooq, and Khawar (2012).Bio-economic Assessment of Different Wheat- canola Intercropping Systems. Int. J. Agric. Biol., Vol. 14, No. 5, 769-774.

Mahdi, S.A., N. A. Mahmood and H. S. Hammad (2011). Effect of intercropping and Agricultural periods into some winter vegetable crops for the quantitative characteristics on broad bean Viciafaba L. var. acwadlgy. Researches of the first International Conference (Babylon and Razi Universities) ISSN 2072-3875.

Mc-Gilchrist, C.A. (1965). Analysis of competition experiments. Biometrics. 21: 975 985. 
Midmore,D.J. (1993). Agronomic modification of resource use and intercrop productivity. Field CropsRes. 34:357-380.

Mohd. Rezaul Islam, Amrita Mukherjee, Khan Golam Quddus, Prashanta Kumar Sardar, and Mosharraf Hossain (2015). Effect of spacing and fertilizer on the growth and yield of onion. International J. of Sci.\& Technology Res. Vol. 4, 308 312.

Sarker, R., M. Ratna, S. Ray, A.H.F. Fahim and M.J. Tithi (2017). Effect of planting method on onion (Allium cepa L.) bulb production in Faridpur region of Bangladesh. Archives of Agric. and Environmental Sci. 2 (2): 63-67.

Snedecor, G.W. and Cochran, W.G. (1967). Statistical methods $6^{\text {th }}$ ed. lowa State Univ. Press Ames., lowa, USA.

Willey, R.W., (1979). Intercropping, its importance and yield advantages. Field Crops Abstr. 32: 1-10.

Zen El-Dein, A.A.M. (2016). Effect of planting methods and NPK fertilizer on intercropping onion with wheat. Al-Azhar J. Agric. Res., Vol. 27, pp 501-515. 


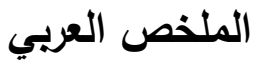

\section{تأثثير طرق الزراعة وتحميل البصل أخضر وناضج مع القمح}

عاطف عبدالجليل مسعود زين الدين' و عبدالعزيز إبراهيم يحيى'

1- قسم بحوث التكثيف المحصولى r- قسم بحوث القمح , معهد بحوث المحاصيل الحقلية , مركز البحوث الزراعية

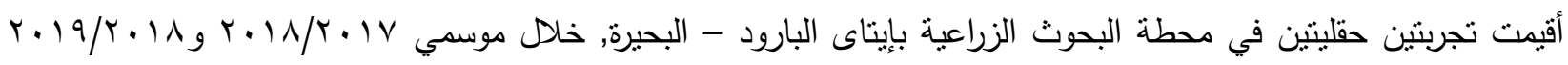

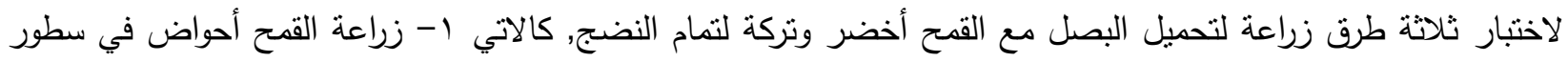

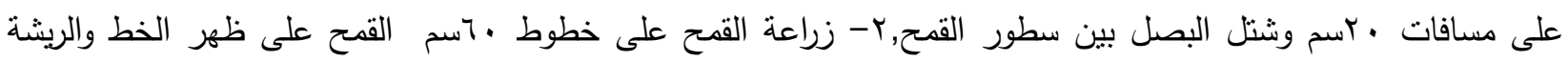

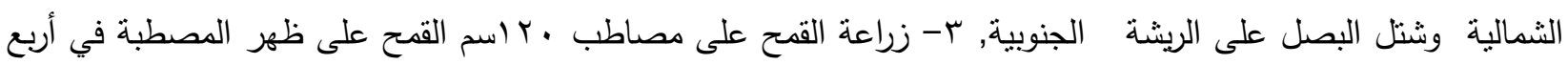

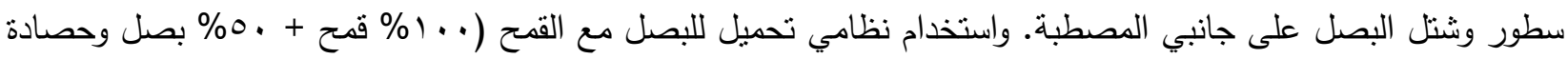

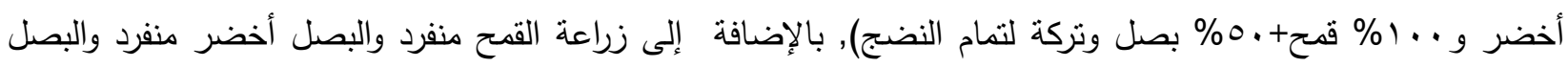
ناضج منفرد.

وكانت أهم النتائج, لم ينأثر محصول القمح ومكوناته بطرق الزراعة في الموسمين, ماعدا طول السنبلة وعدد السنابل /ع ب تأثروا

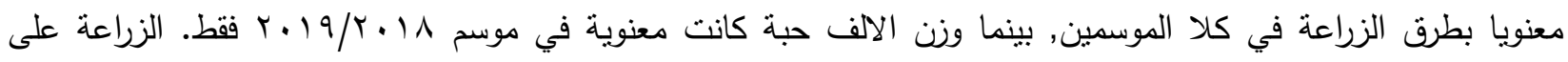

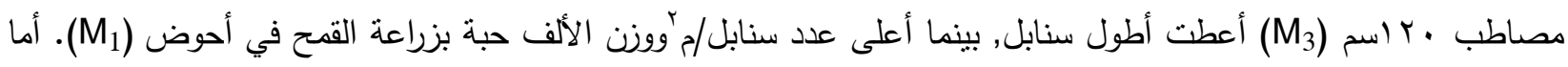

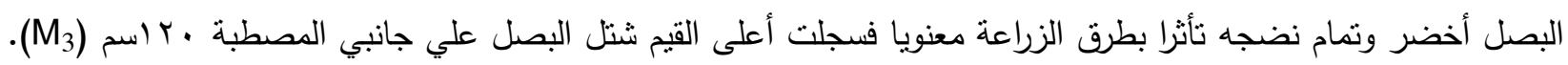

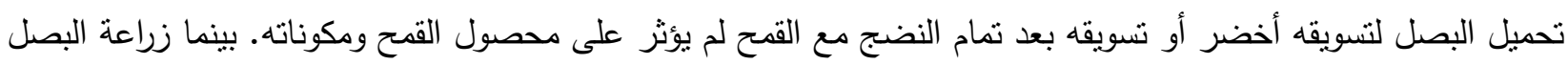
منفردا أعطى أعلى محصول للفدان مقارنة بزراعة البصل محمل.

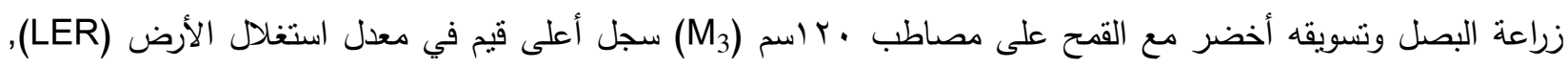

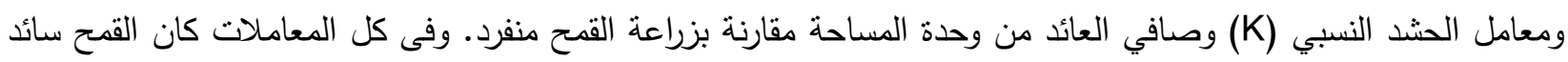
والبصل مسود. 